\title{
Climate Adaptation and Federalism: Mapping the Issues
}

\author{
DANIEL A. FARBER*
}

\section{TABLE OF CONTENTS}

I. A SHORT INTRODUCTION TO CLIMATE ADAPTATION ….................................... 261

II. SetTing AdAPTATION STANDARDS: The ANALOGY TO

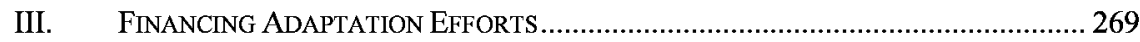

A. State Funding Under the "Beneficiary Pays" Principle ......................... 269

B. Federal Funding and the "Public Pays" Principle ................................ 272

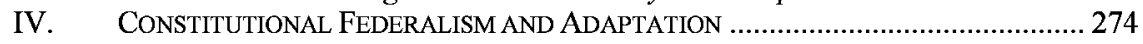

A. Federal Power to Impose Adaptaion Standards .................................. 274

B. Directly Mandating Action by States ............................................... 280

C. Using Fiscal Powers as Leverage ........................................................ 282

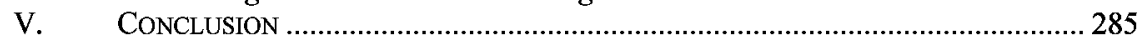

There is a vigorous debate about the appropriate roles of the state and federal governments in reducing greenhouse gases and mitigating climate change. ${ }^{1}$ There has been little if any discussion, however, about the appropriate roles of the states and the federal government in adapting to climate change. Yet significant climate change is unavoidable, and adaptation will be an important and difficult task. It is not too early to begin considering how that task should be allocated between levels of government.

* Sho Sato Professor of Law and Chair, Energy and Resources Group, University of California, Berkeley.

1. See generally Symposium on Federalism and Climate Change: The Role of the States in a Future Federal Regime, 50 ARIZ. L. REV. 673 (2008). 
All levels of government are likely to play some role in mitigation. State and local governments are in some ways the natural "first responders" to climate change. They own or license critical infrastructure, provide health services, and control land use. The federal government, however, may step in to provide mandatory standards for adaptation efforts or finance adaptation. These federal efforts may be subject to certain constitutional constraints that could limit policy responses. Before adaptation needs become truly acute, we need to think about the appropriate roles of state and federal governments.

This Article is a first step in mapping this new terrain. Part I provides a short introduction to climate adaptation. The United States will face significant climate impacts in the next few decades, and governmental responses will be required. ${ }^{2}$ Part II discusses the role of the federal government in setting adaptation standards, while Part III analyzes the appropriateness of state versus federal funding for adaptation. States are likely to play the leading role in funding adaptation and setting standards, but federal intervention may be warranted by the existence of interstate spillover effects, political distortions that hinder state responses, or equity factors. Finally, Part IV considers how constitutional constraints may limit the federal government's role. Under present law, those constraints are mild, but future doctrinal evolution is difficult to predict.

For analytic purposes, this Article will distinguish between mitigation and adaptation as well as between the federal government's regulatory and fiscal roles. But these distinctions are somewhat artificial. As Part I discusses, the same action can both mitigate future climate change and assist adaptation to impending climate change. Similarly, standardsetting and federal funding may be combined. We can expect to see hybrid programs that cross lines between categories.

For instance, consider a federal program that increases recycling and use of gray water by municipalities. Such a program would serve adaptation (by helping cities to cope with less reliable water sources) and mitigation (by reducing energy demands associated with moving water from water bodies or aquifers to urban users). Such a program could also combine funding and regulation. One model would be the Clean Water Act's treatment of municipal treatment plants. The statute requires treatment plants to adopt secondary treatment (and more stringent controls if needed to attain applicable water quality standards) ${ }^{3}$

2. See James E. Neumann \& Jason C. Price, Adapting to Climate Change: The Public POLICY RESPONSE-PUBlic INFRASTRUCTURE (2009), http://www.rff.org/rff/ documents/RFF-Rpt-Adaptation-NeumannPrice.pdf.

3. Clean Water Act, 33 U.S.C. \$ 1311(b)(1)(B) (2006). 
with some provisions for either modifying the requirements ${ }^{4}$ or extending the deadline. ${ }^{5}$ By 1996, Congress had also appropriated $\$ 69$ billion to aid construction of treatment plants. ${ }^{6}$ Although the Clean Water Act has been a mixed success in dealing with municipal wastewater treatment, ${ }^{7}$ its combination of regulation plus funding may appeal to policymakers. It is easy to imagine expansion of this program to a combination of mandates and subsidies for recycling water in order to reduce demand and deal with expected drought conditions.

This is an example of the kind of cooperative federalism that we might expect to see in responses to climate adaptation. ${ }^{8}$ Although reality is less tidy than our analytic categories, we can still gain clarity by drawing conceptual distinctions between adaptation and mitigation as well as between regulation and fiscal measures.

\section{A SHORT INTRODUCTION TO CLIMATE ADAPTATION}

Adaptation to climate change is unavoidable. The fact is that some degree of climate change has already begun, and further change is inevitable. 9 This section will survey some of the most likely impacts of climate change and the sorts of adaptation that may be required.

Climate change will raise sea levels, a simple effect with potentially far-reaching consequences. Sea level rise will have substantial impacts

4. Id. $\S 1311(\mathrm{~h})$.

5. Id. $\S 301(\mathrm{i})$.

6. Congressional Research SERvice, Clean Water Act: A Summary of the LAW 6 (1999), http://www.ncseonline.org/NLE/CRSreports/water/h2o-32.cfm.

7. See generally Ellen Wolfgang, Comment, Reclaiming the Clean Water Act: A New Approach to Wastewater Management, 34 FLA. ST. U. L. REV. 1247 (2007).

8. For a discussion of cooperative federalism, see Holly Doremus \& W. Michael Hanemann, Of Babies and Bathwater: Why the Clean Air Act's Cooperative Federalism Framework Is Useful for Addressing Global Warming, 50 ARIZ. L. REV. 799, 824-29 (2008).

9. Many scientists and policy makers believe that a doubling of $\mathrm{CO} 2$ from preindustrial levels to $550 \mathrm{ppm}$ may be unavoidable in the $21 \mathrm{st}$ century. This is so because the world's political and economic system cannot respond rapidly enough to make faster changes in some major polluting sources such as gasoline-powered automobiles or coalfired power plants. The lag time of $\mathrm{CO} 2$ released from the ocean also contributes to this problem. Even if all nations could have stabilized emissions in the year 2002, the concentrations of GHGs would have continued to rise and would approach $500 \mathrm{ppm}$ by the year 2100. After that, GHG concentrations in the atmosphere would continue to rise for several hundred years before stabilization would be achieved. Even to stabilize $\mathrm{CO} 2$ at $1,000 \mathrm{ppm}$ will require reductions of emissions below current levels. Donald A. Brown, The U.S. Performance in Achieving its 1992 Earth Summit Global Warming Commitments, 32 ENVTL. L. REP. 10741, 10741 (2002). 
on the United States such as causing dramatic losses in wetlands. ${ }^{10}$ Because the slope of coastal areas on the Atlantic and Gulf Coasts is low, a forty-centimeter rise in sea level could result in as much as sixty meters of beach erosion and may cost billions of dollars. ${ }^{11}$ A half-meter sea level rise would place $\$ 185$ billion of property in jeopardy by 2100 , and the cost of protecting developed areas from a half-meter rise would be $\$ 115$ to $\$ 274$ billion. $^{12}$ In Dade County alone, approximately $\$ 10$ billion in property is within 65 centimeters of sea level. ${ }^{13}$ Thus, sea level rise translates into significant increases in flood risks.

Water supply is another key climate impact. Flood risk and water supply issues can be intertwined, as in the California Delta, where potential levee collapses due to flooding would drastically impair water supplies for much of the state. ${ }^{14}$ Meanwhile, in the Southwest, the future of the water supply is uncertain, with potentially major impacts on agriculture. $^{15}$ Recent evidence regarding the Southwest is particularly worrisome:

Scientists also looked at the prospect of prolonged drought over the next 100 years. They said it is impossible to determine yet whether human activity is responsible for the drought the Southwestern United States has experienced over the past decade, but every indication suggests the region will become consistently drier in the next several decades. Richard Seager, a senior research scientist at Columbia University's Lamont-Doherty Earth Observatory, said that nearly all of the 24 computer models the group surveyed project the same climatic conditions for the North American Southwest, which includes Mexico. "If the models are correct, it will transition in the coming years and decades to a more arid climate, and that transition is already underway," Seager said, adding that such conditions would probably include prolonged droughts lasting more than a decade. ${ }^{16}$

10. Denis Culley, Comment, Global Warming, Sea Level Rise and Tort, 8 OCEAN \& COASTAL L.J. 91, 100-01 (2002).

11. See generally David Grossman, Warming UP to a Not-So-Radical Idea: TortBased Climate Change Litigation, 28 COLUM. J. ENVTL. L. 1, 12-14. (2003).

12. William E. Easterling III et. al., Coping with Global Climate Change: The Role of AdAPTATION IN THE UNITED STATES 14 (2004), http://www.carth scape.org/12/ES17424/PEW_Adaptation.pdf.

13. NEUMANN \& PRICE, supra note 2, at 17.

14. Louise Bedsworth \& Ellen HanaK, PREParing California For a CHANGING CLIMATE 8 (2008), http://www.ppic.org/content/pubs/report/R_1108LBR.pdf.

15. See generally Jason Mark, Climate Change Threatens to Dry Up the Southwest's Future, ALTERNET, Oct. 16, 2008, www.alternet.org/story/103366/.

16. Juliet Eilperin, Faster Climate Change Feared: New Report Points to Accelerated Melting, Longer Drought, WASH. POST, Dec. 25, 2008, at A02, available at http://www. washingtonpost.com/wp-dyn/content/article/2008/12/24/AR2008122402174_2.html?hpid= moreheadlines. 
Adaptation of water systems to increased flood and drought risks includes a variety of responses. ${ }^{17}$ Some involve management of water systems through use of longer-range predictions to guide water reservoir use. Managing water demand is another option, including increased use of market transfer among users or conservation and efficiency improvements. It is also important to evaluate the risks to water infrastructure posed by more severe floods, which may require investment in strengthening existing dams and levees. Additional storage capacity (both surface and groundwater) may also be called for.

The challenge of adaptation will be substantial. The Stern Report estimates that the cost of adapting infrastructure "to a higher-risk future could be $\$ 15-150$ billion each year $(0.05 \%-0.5 \%$ of GDP), with onethird of the costs borne by the U.S. and one-fifth borne by Japan."18 The difficulty of adaptation varies directly with the pace of climate change and the potential increase in extreme events. "Extreme events such as floods and drought cause extensive damage to many parts of society, and thus a critical issue for adaptation is the degree to which frequency, intensity, and persistence of extreme events change."19 Simply because of higher sea levels, higher flood levels would result, with a possibility that by the end of the century what are now 100-year floods would become 50 -year or 30-year floods. ${ }^{20}$

Public health impacts of climate change are also a concern. ${ }^{21}$ By midcentury, the number of heat wave days in Los Angeles is expected to at least double over the late twentieth century and quadruple by the end of the century. ${ }^{22}$ One of the most vulnerable group (ages over 65) will double in the United States by $2030 .^{23}$ Higher ozone levels due to the increased temperature will cause additional deaths. ${ }^{24}$ The probability of

17. See generally LeVi D. BREKKE ET AL., Climate ChANGE AND Water Resources MANAGEMENT-A FEDERAL PERSPECTIVE: U.S. GEOLOGICAL SURVEY CIRCULAR 1331, at 29-31 (2008), http://pubs.usgs.gov/circ/1331/Circ1331.pdf.

18. Nicholas SteRn, THE Economics OF Climate Change 417 (2007).

19. EASTERLING III ET AL., supra note 12, at 17.

20. NEUMANN \& PRICE, supra note 2, at 19.

21. See generally BEDSWORTH \& HANAK, supra note 14.

22. Id. at 12 .

23. Jon M. Bailey, Top 10 Rural Issues for Health Care Reform, 2 CTR. FOR RURAL AFF., Mar. 2003, at 3, http://files.cfra.org/pdf/Ten-Rural-Issues-for-Health-CareReform.pdf.

24. Healthy Planet, Healthy People: Global Warming and Public Health, Select Comm. on Energy Ind. \& Global Warming 3 (Apr. 9, 2008) (testimony of Prof. Mark Z. Jacobson), http://www.stanford.edu/group/efmh/jacobson/OralTest0408.pdf. 
large wildfires is also expected to increase by $12 \%$ to $53 \%$ by the end of the century. ${ }^{25}$

Just as climate impacts are multiple, so are adaptation techniques. Adaptation covers a wide spectrum of responses:
The array of potential adaptive responses available to human societies is very large, ranging from purely technological (e.g., sea defenses), through behavioural (e.g., altered food and recreational choices) to managerial (e.g., altered farm practices), to policy (e.g., planning regulations). While most technologies and strategies are known and developed in some countries, the assessed literature does not indicate how effective various options are to fully reduce risks, particularly at higher levels of warming and related impacts, and for vulnerable groups. In addition, there are formidable environmental, economic, informational, social, attitudinal and behavioural barriers to implementation of adaptation. ${ }^{26}$

Few of these measures are costless, and some may turn out to be quite expensive. It remains to be seen how different levels of government will participate in this effort.

State and local governments are beginning to understand the need for adaptation. For instance, Chicago has issued a detailed guide to adaptation for municipalities. ${ }^{27}$ The guide considers a broad range of impacts, including shoreline erosion, invasive species, health threats from heat waves and increased ozone, damage to key infrastructure, and flood damage. $^{28}$

It is important to understand that climate change adaptation and mitigation can overlap. For instance, green building can be a way of mitigating climate change through reduced energy use, but it can also help adapt to climate change through more efficient water use or internal temperature control. The trend toward green building may push some regulatory decision making from the local level to the state level, ${ }^{29}$ and it is easy to imagine that the federal government might step in to promote the move to green building. Similarly, water systems are a significant source of energy use, so water conservation efforts can both respond to climate change and help mitigate future change.

25. Louise Bedsworth, AIr Quality Planning and California's Changing Climate 6 (Pub. Pol'y Inst. of Cal. ed., 2008), http://www.ppic.org/content/pubs/report/ R_1108LB2R.pdf.

26. M.L. Parry et al., Climate Change 2007: ImPacts, Adaptation AND VULNERABILITY: CONTRIBUTION OF THE WORKING GROUP II TO THE FOURTH ASSESSMENT REPORT ON INTERgovernMENTAL PANEL ON ClimAte ChANGE 19 (2007), http://www. ipcc.ch/pdf/assessment-report/ar4/wg2/ar4-wg2-spm.pdf

27. Chicago Climate action Plan, Chicago Area Climate Change Quick Guide: Adapting to the Physical Impacts of Climate Change (Julia Parzen ed., 2008), http://www.chicagoclimateaction.org/filebin/pdf/Chicago_Quick_Guide_to_Climate_ Change_Preparation_June_2008.pdf.

28 . Id. at $12-1 \overline{3}$.

29. See Sara C. Bronin, The Quiet Revolution Revived: Sustainable Design, Land Use Regulation, and the States, 93 MINN. L. REV. 231, 231-33 (2008). 
Some adaptation will happen seamlessly through the private sector or via low-visibility actions by various levels of government. Other adaptation efforts will require significant government expenditures or regulatory initiatives. In the American government system, which divides authority between the federal government and state governments and their municipalities, we can confidently predict disputes about who should take the lead.

\section{SETTING ADAPTATION STANDARDS: THE ANALOGY TO ENVIRONMENTAL REGULATION}

Although the two may be connected in practice, it is useful to distinguish two federal roles. First, the federal government may leave adaptation efforts to the states or the private sectors but mandate that certain standards be met. For instance, it might require that all levees be adequate even if climate change increases future flooding. Second, the federal government might itself undertake adaptation projects or fund projects by states or the private sector. We begin with the first issue in this section, deferring the other issue until the next section.

It is too early to know what policies the federal government will embrace regarding adaptation standards or the degree to which the federal government may be involved. The answer depends in part on how well state governments perform in meeting the adaptation challenge. Direct federal regulation is likely to be a last resort.

Standard-setting does not necessarily equate to explicit regulation of the kind found in federal pollution statutes. The federal government may use other techniques to set uniform standards, such as, conditioning state funding on a state's adoption of federal standards. It may also use as sources of leverage other federal programs, such as flood insurance, water supply contracts from federal projects, federal licensing or funding of infrastructure projects, or conditions on agricultural subsidies.

To get a sense of the range of possibilities, we might consider the following as a sample of potential areas for new federal standards:

- Efforts to deal with the increased risk of floods, such as (a) limitations on infrastructure construction in flood plains or coastal areas, (b) mandates to relocate some existing infrastructure inland, or (c) minimum performance standards for levees, including those owned by state or local governments or private parties. 
- Restrictions on building in areas that will be subject to wildfires in hotter, dryer conditions.

- Measures to deal with the threat of increased drought, including (a) water allocations between states during drought periods, (b) multistate or nationwide requirements for water conservation for irrigation or municipal water systems, or (c) bans on the production of crops such as rice or cotton in irrigated areas.

- Modification of the Endangered Species Act to require landowners to preserve habitats not currently used by an endangered or threatened species, when climate change is likely to force the species to relocate to that habitat.

In addition, climate impacts might be managed in part through current federal law. Stricter control of water pollution may be needed to attain existing water quality standards in order to counter the effects of higher temperature or decreased flow. Similarly, higher temperatures could increase ozone levels in cities, requiring stricter pollution controls to meet air pollution standards that are already on the books. Likewise, the Endangered Species Act may require actions to maintain minimum flows during drought periods, which in turn would require water conservation by other users, and perhaps increased storage facilities.

Thus, although new forms of direct federal regulation may not seem a strong possibility, at present, there are a variety of other ways in which federal adaptation standards might emerge. In considering how much of a role the federal government should play, we can learn from the existing debate about the federal role in environmental regulation. Understanding the reasons for a federal role in environmental law may illuminate arguments for a federal role in adaptation policy.

Why shouldn't environmental protection be left to the states, as it generally was until forty years ago when Congress began to enact modern environmental statutes? ? $^{30}$ One reason is that environmental problems themselves may cut across jurisdictional lines. As Richard Revesz has pointed out, the economic argument for a coordinated solution in this situation is undeniable. ${ }^{31}$ For a similar reason, adaptation efforts may cross state lines-for example, failure to conserve water in

30. This historical evolution is discussed in Richard J. Lazarus, The Greening of America and the Graying of United States Environmental Law: Reflections on Environmental Law's First Three Decades in the United States, 20 VA. ENVTL. L. REV. 75 (2001). Richard B. Stewart, Environmental Quality As a National Good in a Federal State, 1997 U. CHI. LEGAL F. 199 (1997) provides a defense of this development.

31. Richard Revesz, Federalism and Interstate Environmental Externalities, 144 U. PA. L. REV. 2341, 2387 (1996). 
one state may decrease the amount available to users in another state or may impair other values of the water body, such as biodiversity.

Such spillover effects are relevant to adaptation issues. When watersheds cross state lines, flood control efforts in one area may affect another. In arid areas, failure by water users in one state to conserve may mean that less water is available for downstream users. The spread of invasive species due to climate change may also cross state lines, as do impacts on migratory native species or species whose ranges may be pushed northward due to climate change. Invasive species that carry diseases, such as malaria mosquitoes, are a particular concern. ${ }^{32}$ As illustrated by Hurricane Katrina, major disasters may also displace large populations, imposing costs on communities outside their state of origin. Furthermore, infrastructure that is exposed to climate impacts, such as highways, railroads, power lines, and pipelines, may suffer service interruptions that impact businesses and individuals well outside a state's borders.

Another type of spillover is economic rather than environmental. In a world of capital mobility, regulatory efforts may be stymied by capital flight. In order to attract and retain industry, a jurisdiction may lower its environmental standards only to spark a round of similar responses from other jurisdictions. Similarly, in order to attract new business, states might fail to impose stringent energy or water conservation standards on buildings, or to keep taxes low, states might neglect infrastructure projects that would help reduce climate impacts. The result is a race to the bottom, in which jurisdictions compete by progressively lowering their environmental standards until they hit rock bottom. ${ }^{33}$ Only the intervention of a centralized authority can halt this destructive competition between jurisdictions. As Revesz explains, under this "race to the bottom" model, local jurisdictions would face a prisoner's dilemma so that federal regulation can be seen "not as an intrusion on the autonomy

32. See, e.g., Amy Greer, Victoria $\mathrm{Ng}$ \& David Fisman, Climate Change and Infectious Diseases in North America: The Road Ahead, 178 CANADIAN MEDICAL ASSOCIATION JOURNAL 715 (2008).

33. For discussions of the race to the bottom, see DAVID L. SHAPIRO, FEDERALISM: A DiAlogue 42-43, 81-82 (1995); Richard L. Revesz, Rehabilitating Interstate Competition: Rethinking the "Race-to-the-Bottom" Rationale for Federal Environmental Regulation, 67 N.Y.U. L. REV. 1210 (1992). In the trade context, see Robert E. Hudec, Differences in National Environmental Standards: The Level-Playing-Field Dimension, 5 MinN. J. Global Trade 1 (1996). 
of states, as it is often portrayed, but rather as a mechanism by which states can improve the welfare of their citizens." ${ }^{934}$

Considerable dispute exists among scholars regarding the "race to the bottom" rationale. Under many conditions, just as competitive markets for goods can produce efficient results, interstate competition can produce economically efficient environmental regulation. However, economic theory suggests four circumstances in which the race to the bottom may occur, justifying some multijurisdictional solutions. ${ }^{35}$

First, local governments may be forced to use flawed methods of taxation, leading to distortions in other regulations in an effort to attract business. An example might be California's Proposition 13, which virtually freezes the property taxes of existing business locations and, hence, provides a special incentive to obtain tax revenue from new businesses. $^{36}$ Another fiscal distortion is that municipalities might obtain the fiscal benefits of new development without facing costs for disaster response, which may be borne by higher levels of government. This would encourage adoption of weak disaster prevention standards.

Second, competition in product or capital markets may be imperfect, leading to efforts by states to capture firms or monopoly profits, or to avoid unemployment. For example, because OPEC sets prices above the competitive level, the oil industry enjoys monopoly profits on oil because of OPEC's price-setting activities, increasing the incentive to engage in potentially harmful activities in coastal areas that may increase risks from sea level rise or increased storm surges. State governments may tolerate these risks in return for a share of these firms' monopoly profits in the form of taxes or leasing fees.

Third, public choice problems may distort local decisions, leading to capture of the regulatory process by industry. Real estate developers, for instance, may have undue influence on land use decisions. This might lead to excessive development of vulnerable regions, such as low-lying areas. Political influence by industry could also lead to destruction of wetlands that buffer storm surges.

34. Revesz, supra note 33, at 1218.

35. See Daniel Farber, Environmental Federalism in a Global Economy, 83 VA. L. REV. 1283 (1997). For Revesz's defense of his theory, see Richard L. Revesz, The Race to the Bottom and Federal Environmental Legislation: A Response to Critics, 82 MinN. L. REV. 535 (1997). A survey of the relevant economic literature seems to suggest that the race to the bottom is a genuine possibility though by no means inevitable. See Bratton \& McCahery, The New Economics of Jurisdictional Competition: Devolutionary Federalism in a Second-Best World, 86 GEO. L.J. 201 (1997).

36. For an explanation of the operation of Proposition 13, see California Tax Reform Association, Rethinking Proposition 13, http://caltaxreform.org/? $\mathrm{p}=5$ (last visited Nov. 3, 2009). 
Fourth, jurisdictions may be large enough to affect global prices, leading to protectionist policies. For instance, a country that controls a major global industry might use a high level of regulation as a way of providing benefits to local residents while the costs are passed on to foreign consumers. This factor, however, does not seem particularly relevant to climate adaptation.

Thus, the race-to-the-bottom question is potentially relevant to climate adaptation standards. For instance, local jurisdictions that are eager to attract new development might allow building in flood plains or encourage unwise development by providing subsidized insurance against storm or flood damage. When the financial burden of resulting harms can be shifted to the federal government, such as in the form of federal disaster relief, states may have a lower incentive to regulate in order to avoid potential harms than if the state government itself had to pay for the harm.

Nevertheless, in the context of climate adaptation, spillover effects are probably a more compelling reason for federal intervention than the race to the bottom. Other federal intervention may be ancillary to mitigation efforts - for example, requirements for water conservation in order to reduce water-related energy usage. In addition, some states may be lacking in the technical capacity to implement their own adaptation planning effectively.

No doubt, much of the adaptation effort will be entirely within state control, but there is a definite argument for some federal role in setting adaptation standards. No doubt there will also be arguments for federal funding of adaptation projects as well, a topic considered in the next section.

\section{FINANCING ADAPTATION EFFORTS}

Adaptation will not be cheap. In terms of federalism, the question is how financial responsibility will be divided between the federal government and the states. Will states finance all or most adaptation, or will the federal government pick up most of the expense?

\section{A. State Funding Under the "Beneficiary Pays" Principle}

It is easy to construct an argument in favor of leaving the financial responsibility for climate adaptation with the States. Normally, people have to pay for goods and services if they want to consume them-at 
least, this is the theory of a market economy. When the private market is unable to produce certain goods, perhaps because of collective action problems, the government steps in. The basic principle that the cost of producing goods should be borne by those who benefit from them remains appealing. On this theory, the individuals who benefit from adaptation should pay the cost. Usually, this theory would mandate state financing of adaptation efforts that benefit local citizens.

On an analogous issue in the theory of taxation, Eric Rakowski suggests that:

[a] nation committed to protecting its citizens as equals will attempt to maintain its borders and to supply people living throughout its territory with basic protection. But it cannot fully equalize protections throughout, at least not if it taxes all the same, so that those who choose to live in certain areas know that they take on some risks and costs, perhaps including private protection, as the price of their decisions. Privately purchased protection or the assumption of additional risk, coupled with equal taxes, is tantamount to equal protection with unequal tax payments. ${ }^{37}$

In simpler terms, people who choose to live in riskier areas cannot fairly demand that their fellow citizens pay to provide them protection from these risks. We can call this the "Beneficiary Pays" adaptation principle: beneficiaries of adaptation should pay for adaptation.

The Beneficiary Pays adaptation principle would seem to call for placing the responsibility for adaptation at the lowest possible governmental level so that both costs and benefits would be concentrated on the same group. Thus, coastal measures might be financed by coastal states, or even better, by coastal counties within those states. Sometimes an adaptation project's beneficiaries will not correspond to any existing political entity. States might respond by creating a special purpose entity; it is easy to imagine climate change adaptation districts like today's drainage or irrigation districts.

Alternatively, states might finance adaptation projects through special tax assessments on the beneficiaries, just as the owners of property may have to pay a special assessment to finance sidewalks or other improvements. For instance, if new varieties of wheat are needed because of climate change, wheat farmers might pay a special fee to help develop the new varieties, or if a flood zone needs additional levees, landowners might pay a special tax.

On one hand, Beneficiary Pays is an appealing adaptation principle in terms of eliminating moral hazard and rent-seeking. If project beneficiaries have to pay for projects, they are unlikely to want to

37. Eric Rakowski, Can Wealth Taxes be Justified?, 53 TAX L. REv. 263, 305 n.75 (2000). 
overinvest beyond the project's benefits or to lobby the government for projects that will raise their taxes more than any corresponding benefit they receive. On the other hand, if someone else is paying, localities may demand unwarranted adaptation efforts either out of an abundance of caution regarding adaptation needs or simply to bring additional construction employment to the locality. To the extent that we are concerned about overinvestment in adaptation, Beneficiary Pays is the best solution.

However, Beneficiary Pays, as applied to adaptation, does not advance other possible social goals. It provides little incentive for pollution emitters to mitigate because the burden of adaptation costs falls on beneficiaries of projects, who suffer from climate impacts, rather than the emitters who cause the impacts. (To the extent that areas with high adaptation costs happen to coincide with areas with large emissions, it does provide governments a small additional incentive to reduce local emissions so as to reduce their own future adaptation costs.) It leaves the costs of climate change where it finds them, doing nothing to advance loss spreading as a form of social insurance. Furthermore, to the extent that we view emitters as culpable or unjustly enriched by their failure to mitigate, Beneficiary Pays does not advance the concept of just desserts. Finally, because benefits and costs fall on the same individuals, Beneficiary Pays also fails to serve any redistributive goal, and we may be concerned that poorer areas of the country will lack the financial or institutional capacity to manage adaptation.

Whether these are serious shortcomings depends, in part, on whether these other social goals are viewed as important. It also depends on whether we have alternative methods to advance those goals. For example, if we have optimum mitigation requirements, complete insurance for all risks, and a fiscal system that achieves our desired income distribution, we do not need to rely on adaptation financing to help achieve those goals. We may also think that principle of just desserts is not a valid goal for social policy, or that the circumstances of climate change do not involve any principle of just deserts. Thus, evaluating the normative appeal of Beneficiaries Pay may be complicated.

There are also practical issues to be considered. Determining the beneficiaries of a given adaptation project may be straightforward, thus limiting transaction costs. Yet this will not always be true. Adaptation projects may indirectly benefit other sectors of society. For example, a water storage project may primarily benefit users in the immediate area, 
but it may also offer a potential fallback supply to other users in unusual drought conditions. This is a particularly significant question with interstate waters, such as the Colorado River. Adaptation in one area may prevent local residents from moving elsewhere, which would have created the need for public services and infrastructure in those locations. Disputes over how benefits are allocated could become quite heated, with expert witnesses marshalling the evidence for attributing benefits in different ways.

Beneficiary Pays clearly supports use of state financing when beneficiaries of an adaptation measure are in-state. Such a system is also supported when mitigation incentives, loss spreading, and just desserts are seen as unimportant or irrelevant, or these other goals are addressed through different mechanisms. Thus, as a policy matter, much of the burden of adaptation should be on the state level. However, this does not mean that the federal government should be completely uninvolved, as we will see in the next section.

\section{B. Federal Funding and the "Public Pays" Principle}

The alternative is for the cost of adaptation to fall on the federal taxpayer. ${ }^{38}$ The underlying adaptation principle could be called "public pays," which rests on the premise that society as a whole should protect individuals from certain kinds of harm such as climate change. This system achieves the maximum amount of loss-spreading, in essence providing social insurance against the risk of climate change. It expresses the idea that climate change is a national problem, thus, emphasizing national solidarity in the face of the threat. To the extent we are satisfied with the tax system in distributional terms, it also provides the right distributional result for climate costs.

We can imagine several ways for this principle to be implemented. The federal government might simply take adaptation as its own responsibility and pay for projects directly from the Treasury. Alternatively, state and local governments might receive federal grants to engage in

38. For present purposes, it is irrelevant whether the government finances projects directly through taxes or by issuing bonds, which will later result in payments financed through taxes. It would make a difference, however, if imperfections in the bond market allowed the government to transfer some of the costs away from taxpayers to bondholders. This might have different loss-spreading and distributional effects than taxation, depending on the identity of the taxpayers. For example, if the federal government sold all of the bonds to foreigners and then defaulted, the taxpayers might escape any financial responsibility (though the government's credit might be impaired.) On the other hand, if the government did not default, then adaptation costs would be pushed later in time to fall on the shoulders of later taxpayers when the bonds are paid off. 
adaptation, or private sector actors might receive tax credits or other subsidies.

Although it rates well in terms of loss-spreading, federal funding is problematic along other dimensions. Particularly, it maximizes the potential for moral hazard and rent seeking, since localities have an incentive to seek financial funding above and beyond their true adaptation needs. In the worst-case scenario, climate adaptation might become one of the biggest pork barrels in history.

Use of federal funds may be particularly attractive, however, when it can be used as a mechanism to place adaptation costs on emitters. This can be justified on the basis of fairness because emitters knowingly contribute to intensifying an already harmful situation and in the process may save the costs of emission reduction. Using a carbon tax or proceeds from auctioning emissions allowances to fund adaptation redistributes funds from emitters to victims of climate change. Thus, "federal taxpayer pays" is a potentially plausible basis for reallocating some adaptation costs to emitters, which could be more easily done at the federal level.

In short, federal financing of adaptation is appealing when the need for adaptation is easily monitored (reducing the incentive to rent-seek), when there is little risk that adaptation will cause undesirable reductions in self-protective action by beneficiaries, when doing so addresses wealth inequalities between states, and when the cost can be shifted to emitters. As with setting adaptation standards, the strongest argument for federal funding is probably spillover effects. When infrastructure projects or other adaptation efforts affect multiple states, a federal financing role is appropriate.

These arguments point toward a real but limited federal role. Adaptation projects should not be federally funded when there are no spillover effects across state lines, no obstacles to state provision of the adaptation, and no strong claim for national solidarity. Still, this leaves a substantial category of cases in which federal funding is appropriate.

Regardless of these policy arguments, we can probably anticipate a major federal role in financing adaptation. In 2006, the federal government spent $\$ 76$ billion on infrastructure, and over the past decades federal infrastructure spending has risen about two percent 
annually. ${ }^{39}$ This is about a quarter of total infrastructure spending. ${ }^{40}$ There is no reason to think that the federal government will play a smaller role in infrastructure expenditures due to climate change.

\section{CONSTITUTIONAL FEDERALISM AND ADAPTATION}

So far, we have been concerned with the policy question of what roles should be played by the states and the federal government. We must also consider the constitutional question as to what role the federal government can play. ${ }^{41}$ Briefly, the federal government can (a) adopt adaptation standards applicable to private parties; (b) adopt standards to govern state activities, (c) attempt to mandate that states adopt and enforce adaptation standards; or (d) place conditions on funding to obtain compliance with federal standards.

\section{A. Federal Power to Impose Adaptation Standards}

State regulations might run afoul of federal preemption or, conceivably, the dormant commerce clause, although neither issue seems immediately apparent for state restrictions on land or water use, construction codes, or other types of state regulatory standards. ${ }^{42}$ Thus, constitutional issues with state adaptation standards are not likely to be pervasive. Some federal adaptation measures, however, might encounter constitutional challenges.

For instance, the federal government might impose water-use restrictions on upstream users in the case of a severe drought on an interstate water body. The users in question might be commercial or residential. The federal government may also want to protect isolated wetlands or other habitats to assist species that have suffered from climate impacts. Such measures might be attacked as exceeding Congress's legislative authority under the commerce clause.

The commerce clause gives Congress the power to regulate interstate and foreign commerce. Until the late nineteenth century, this provision

39. Congressional Budget Office, Trends in Public Spending on TRANSPORTATION AND WATER INFRASTRUCTURE, 1956-2004, at 3 (2007).

40. Id.

41. There are also possible constitutional issues about state efforts, but they are more likely to involve takings issues, such as the ability of states and cities to ban floodplain development.

42. Cooperative efforts between states might also run afoul of the Compact Clause in the absence of congressional approval, and it is also conceivable that cooperative agreements between states and Canada or Mexico to deal with common problems might be subject to foreign affairs preemption. For background on the compact clause and foreign affairs preemption, see Daniel A. Farber, Climate Change, Federalism, and the Constitution, 50 ARIZ. L. REV. 879, 904-10 (2008). 
did not cause much legal perplexity simply because Congress rarely attempted to use this power. ${ }^{43}$ With the rise of the modern regulatory state, all of that changed. ${ }^{44}$ The cases since the Civil War can be divided into three periods.

The first period began around 1890 when Congress became active in regulation and ended abruptly during the New Deal. The Court vigorously policed federal legislation to ensure that laws were limited to interstate transactions rather than regulating local matters. Agriculture, manufacture, and mining were not considered to be "commerce," nor were local retail transactions. ${ }^{45}$ Thus, much of what the federal government now regulates was considered off limits during this time period. $^{46}$

The Court was not absolutist even during this period. Rather, as discussed below, it was sometimes willing to allow federal regulations that were directed at noncommercial goals or that reached intrastate transactions. An understanding of these doctrines is needed to comprehend later developments. Three major exceptions existed to the general requirement that the object of regulation be some essentially interstate aspect of the transaction. First, Congress could close interstate commerce to noxious items or persons, even if they caused no harm while actually in transit. ${ }^{47}$ For instance, it could ban the interstate sale of lottery tickets even though the actual transportation of the pieces of paper across state lines was harmless. ${ }^{48}$ Second, Congress could regulate local actors or events if they were part of the "stream of commerce." 49 Thus, when cattle were shipped into a state to be slaughtered, with the meat being almost immediately shipped out to other states, the local operations of a slaughterhouse could be regulated. ${ }^{50}$ Third, Congress

43. Daniel A. Farber et al., Cases and Materials on Constitutional Law: THEMES FOR THE CONSTITUTION's THIRD CENTURY 839 (4th ed. 2009).

44. Id. ("This changed after the Civil War and the industrialization of the United States.").

45. See Hammer v. Dagenhart (The Child Labor Case), 247 U.S. 251, 272 (1918) (citing Del., Lackawanna \& W. R.R. Co. v. Yurkonis, 238 U.S. 439 (1915)) (finding no jurisdiction over labor relations of companies involved in interstate commerce); United States v. E.C. Knight Co., 156 U.S. 1, 13 (1895) (holding antitrust laws unconstitutional as applied to national monopoly of sugar manufacturing).

46. See FARBER ET AL., supra note 43 , at 839-50.

47. See id. at 840-41 (interstate and international contagion theory of regulation).

48. Champion v. Ames (The Lottery Case), 188 U.S. 321,353 (1903).

49. See FARBER ET AL., supra note 43, at 843-44.

50. Swift v. United States, 196 U.S. 375, 398-99 (1905). 
could regulate local transactions that had a sufficient impact on interstate commerce by preventing state regulators from shifting costs from local rail shipments to interstate shippers. ${ }^{51}$ However, these exceptions were not construed broadly enough to save much of the early New Deal legislation from the constitutional axe. ${ }^{52}$

The collision between the Court and the New Deal resulted in the famous "switch in time that saved nine" of 1937, when the Court reversed itself under fierce political pressure and began to uphold New Deal legislation. ${ }^{53}$ Whether the political pressure directly caused the switch is debated among modern constitutional historians, ${ }^{54}$ but within a few years, Roosevelt's appointments had transformed the composition of the Court. $^{55}$ From 1937 to 1995 , the Supreme Court rejected every commerce clause challenge to federal regulation of the private sector, without exception. ${ }^{56}$

Until recently, it was safe to say that the commerce power was effectively unlimited. Cases such as Hodel $v$. Indiana gave such a high degree of deference to Congress that almost any imaginable statute seemed likely to be upheld. ${ }^{57}$ For this reason, the Court's decision in United States v. Lopez, ${ }^{58}$ which opened the third period of commerce clause history, surprised many observers. A majority of the Court in Lopez departed from almost sixty years of past practice by ruling that Congress had exceeded its powers under the commerce clause in a regulation of private activity. Specifically, the Court struck down a federal statute prohibiting the possession of firearms in the vicinity of schools.

Chief Justice Rehnquist's opinion for the five-Justice majority in Lopez attempted to limit the commerce power, without overruling any

51. See Houston, E. \& W. Ry. v. United States (The Shreveport Rate Case), 234 U.S. 342, 351-55 (1914) (explaining that Congress has authority to prevent a state's unreasonable discrimination in shipping rates between intrastate and interstate carriers).

52. See, e.g., United States v. Butler, 297 U.S. 1, 53 (1936); Carter v. Carter Coal, 298 U.S. 238, 278 (1936); R.R. Ret. Bd. v. Alton R.R. Co., 295 U.S. 330, 360-61 (1935).

53. The decisive cases were NLRB v. Jones \& Laughlin Steel Corp., 301 U.S. 1 (1937) and United States v. Darby, 312 U.S. 100 (1941). For a discussion of the "switch in time," see Richard Friedman, Switching Time and Other Thought Experiments: The Hughes Court and Constitutional Transformation, 142 U. PA. L. REV. 1891 (1994).

54. See Daniel A. Farber, Who Killed Lochner?, 90 GEO. L.J. 985, 985-86 (2002).

55. See FARBER ET AL., supra note 43, at 34.

56. See Katzenbach v. McClung, 379 U.S. 294, 295 (1964); Heart of Atlanta Motel, Inc. v. United States, 379 U.S. 241, 242-43, 261-62 (1964); Wickard v. Filburn, 317 U.S. 111, 113-14, 128-29 (1942); Darby, 312 U.S. at 105, 121-23, 125-26 (1941); Jones \& Laughlin Steel Corp., 301 U.S. at 22, 25, 30-31, 47, 123, 125-26 (1937).

57. See Hodel v. Indiana, 452 U.S. 314, 324 (1981) ("The pertinent inquiry therefore is not how much commerce is involved but whether Congress could rationally conclude that the regulated activity affects interstate commerce.").

58. United States v. Lopez, 514 U.S. 549 (1995). 
cases or imperiling any well-entrenched federal programs. ${ }^{59}$ The opinion begins by invoking the original understanding that federal powers are "few and defined," while state powers are "numerous and indefinite." $" 60$ Rehnquist emphasized that the original function of this division of powers was to assist in preserving liberty. ${ }^{61}$ Admittedly, he added, the scope of federal power had greatly increased in the post-New Deal era, partly because of "great changes" in the economy and partly because of a desire to eliminate what were considered "artificial" restraints on federal power. ${ }^{62}$ Having analyzed the post-New Deal case law, however, Rehnquist concluded that the statute limiting possession of firearms within the vicinity of schools did not fall squarely within the previously recognized scope of congressional power. He declined to expand that scope further. ${ }^{63}$ In reaching this conclusion, he noted that the statute related to education, which was traditionally a core area of state concern, that Congress had made no findings at the time about the effect of the prohibited activity on interstate commerce, and that the statute required no proof of any nexus between the defendant's activity and interstate commerce. ${ }^{64}$

The Supreme Court has yet to declare any federal environmental regulation to be outside the scope of Congress's commerce power, though it has sometimes found that statutes violated state governmental immunities. $^{65}$ Nevertheless, the Court used Lopez as a justification to read the Clean Water Act narrowly in Solid Waste Agency of Northern Cook County [SWANCC] v. U.S. Army Corps of Engineers. ${ }^{66}$ The question before the Court was whether SWANCC needed a federal permit before filling an abandoned gravel pit. Under the statute, federal jurisdiction covers "navigable waters," further defined as the "waters of

59. Id.

60. Id. at 552.

61. Id.

62. Id. at 556 .

63. Id. at 567-68.

64. Id. at 561-68.

65. See New York v. United States, 505 U.S. 144 (1992) (striking down federal regulation of nuclear waste on the ground that it "commandeered" state legislatures into enforcing federal law).

66. See Solid Waste Agency of N. Cook County v. U.S. Army Corps of Eng'rs, 531 U.S. 159, 162, 173-74 (2001) (citing Lopez and explaining that the Supreme Court has held that Congress's authority under the Commerce Clause is broad but not unlimited, then ruling that the Army's interpretation of the federal regulation in question was too broad.) 
the United States." The federal government asserted jurisdiction over the gravel pit under the Army Corps" "migratory bird" regulation, which claimed jurisdiction over intrastate waters that can be used by migratory birds. The Supreme Court held that the regulation went beyond the Corps' statutory authority. The Court expressed considerable doubt about whether the commerce clause would support the migratory bird rule and construed the statute to avoid this constitutional doubt. Finding "nothing approaching a clear statement from Congress," the Court rejected what it viewed as a "significant impingement of the States" traditional and primary power over land and water use." In the more recent case of Rapanos v. United States, ${ }^{67}$ the Court attempted (not very successfully) to provide guidelines for determining which wetlands fall within the federal government's statutory authority but notably failed to explore potential constitutional concerns. ${ }^{68}$

There are several areas relevant to adaptation in which the new federalism decisions may conceivably threaten federal environmental regulation. The most vulnerable regulations are those that do not directly address interstate effects or specifically target commercial activities. For instance, the Safe Drinking Water Act imposes drinking water standards on public water supplies, which are often provided by local government. ${ }^{69}$ To the extent that these activities are considered noncommercial, Lopez might limit federal regulation. ${ }^{70}$ The Endangered Species Act regulates the "taking" of endangered species, ${ }^{71}$ which includes some forms of habitat modification. ${ }^{72}$ It may debatable whether a particular species has any actual effect on commerce, and the activity

67. Rapanos v. United States, 547 U.S. 715, $731-37$ (2006). For an analysis of the contesting worldviews behind the various opinions on the case, see Jonathan Z. Cannon, Words and Worlds: The Supreme Court in Rapanos and Carabell, 25 VA. ENVTL. L.J. 277, 278 (2007).

68. For attempts to sort out the mess, see Bradford C. Mank, Implementing Rapanos-Will Justice Kennedy's Significant Nexus Test Provide a Workable Standard for Lower Courts, Regulators, and Developers?, 40 IND. L. REV. 291, 294-95, 348 (2007); Jon A. Mueller, Adjacent Wetlands: Is Your Nexus Significant? Rapanos $v$. United States, 38 ENV'T REP. (BNA) 585 (2007). For an illustrative case, see Friends of Pinto Creek v. EPA, 504 F.3d 1007, 1011 (10th Cir. 2007).

69. 42 U.S.C. $\$ 300 \mathrm{~g}-1$ (1996).

70. John Dwyer, The Commerce Clause and the Limits of Congressional Authority to Regulate the Environment, 25 ENVTL. L. REP. (ENVTL. L. INST.) 10421, 10427-28 (1995). The D.C. Circuit recently rejected a facial attack on the statutory ground that the SWDA is, at a minimum, constitutional as applied to utilities that sell drinking water across state lines. See Nebraska v. EPA, 331 F.3d 995, 997, 999 (D.C. Cir. 2003).

71. Endangered Species Act, 16 U.S.C. $\$ 1538$ (1973).

72. See Babbitt v. Sweet Home Chapter of Cmtys. for a Greater Or., 515 U.S. 687, 691, 708 (1995) (upholding regulation limiting habitat modifications affecting endangered species). 
in question may not be commercial. ${ }^{73}$ The Clean Air Act mandates reductions in air pollution levels that may require controls on sources such as leaf-burning, residential fireplaces, personal driving, and barbeques, as well as pollution from government-owned vehicles and buildings. ${ }^{74}$ Such pollution may or may not have any measurable interstate effects.

In Gonzalez v. Raich, the Court placed an important limitation on Lopez by reaffirming that Congress can regulate purely local activities under certain conditions. ${ }^{75}$ If they are part of a class of activities that have a substantial cumulative effect on interstate commerce, where excluding the local activities from regulation might undermine the regulation of the interstate market, they can be regulated. ${ }^{76}$ Justice Scalia emphasized in a concurring opinion that the regulation in Lopez had not been part of a larger regulation of economic activity. ${ }^{77}$ Thus, there seems to be a solid majority for allowing regulation even of purely "local" activities as an ancillary part of comprehensive federal regulation.

To the extent that Congress's power over adaptation is subject to constitutional limits, creative responses may be possible. Environmental trading systems may provide one way to expand the federal government's effective reach. Consider the problem of protecting wetlands from development, which may be particularly important because of the stress placed on the wetlands inventory by climate change. ${ }^{78}$ The government might allow banking of isolated wetlands (over which it arguably does not have jurisdiction) to be used for mitigation by developers of other wetlands over which it does have

73. Thus far, the ESA has withstood such constitutional attacks. See, e.g., Rancho Viejo v. Norton, 323 F.3d 1062, 1068 (D.C. Cir. 2003); Gibbs v. Babbitt, 214 F.3d 483, 486-87 (4th Cir. 2000) (upholding a regulation that prohibited the taking of red wolves on private lands). For more discussion on interstate commerce issues and the ESA, see John Nagle, The Commerce Clause Meets the Delhi-Sands Flower-Loving Fly, $97 \mathrm{MICH}$. L. REV. 174, 184-87 (1998).

74. Clean Air Act, 42 U.S.C. $\$ \S 7401-7626$ (2006).

75. Gonzalez v. Raich, 545 U.S. 1, 9 (2005).

76. Id. at $16-17$

77. For discussion of the environmental implications of Raich, see Bradford C. Mank, After Gonzales v. Raich: Is the Endangered Species Act Constitutional Under the Commerce Clause?, 78 U. CoLo. L. REv. 375, 375-76 (2005).

78. See National Association of State Wetlands Managers, Wetlands Science, http:// www.aswm.org/science/climate_change/climate_change.htm (last visited Nov. 3, 2009). 
jurisdiction. ${ }^{79}$ Such use of isolated wetlands for mitigation would not exceed the commerce power, for the only actual regulation that takes place involves non-isolated wetlands over which the government does have clear jurisdiction. That the owners of such covered wetlands choose to meet their mitigation obligations through restoration or preservation of isolated wetlands is not the government's regulatory mandate.

Arguably, once a banking system is established, the banking system itself becomes a form of interstate commerce. This justifies federal regulation because the isolated wetlands are now directly involved in interstate transactions. This may seem like a form of boot-strapping, but, in theory, the federal government's power over commerce should not depend on whether the market in question is "natural" or created by government intervention. For example, the market in government bonds is surely a form of interstate commerce subject to federal regulation. There is no doubt that the Supreme Court would be quite skeptical if it appeared that the trading system was established or intrastate actors were included within the market solely to establish a foothold for the commerce power. The Supreme Court might be more sympathetic if the federal market merely subsumed preexisting state markets or if the inclusion of the intrastate sources took place as the result of private initiatives.

In the end, the barriers to the federal government's issuance of adaptation regulations are more likely to be political than constitutional. Adaptation involves areas such as water law and land use that have traditionally, and to a large extent, been left to the states. Federal incursions on those domains will encounter political resistance, in addition to whatever threat of judicial resistance may exist.

\section{B. Directly Mandating Action by States}

When the federal government regulates private entities, it may also impose the same requirements on state and local governments. As discussed in the next paragraph, such regulation of state and local governments is within Congress's power-the states have no special immunity from the kinds of regulations that apply to private actors.

The Court in Garcia v. San Antonio Metropolitan Transit Authority overruled National League of Cities $v$. Usery, in which the Court limited the federal government's ability to interfere with the integral governmental

79. Some difficult design questions might be posed by such a system in order to prevent credits for lands that would not have been developed in any event. 
functions of state and local governments. ${ }^{80}$ Under Garcia, federal regulation of state activities is valid to the same extent as regulation of private parties. ${ }^{81}$ State governments, like private parties, must rely on the political process to protect themselves against over-extension of federal power.

Thus, there should be no constitutional issue with federal standards regarding a wide range of activities. The federal government should be able to create standards for state levees to the same extent as private levees, to limit construction of state government structures in flood plains or other vulnerable areas, or to regulate state-provided or statesubsidized insurance programs.

Regulating the activities of states is one thing; requiring states to regulate private parties is quite another. In New York v. United States, the Court held that Congress cannot under any circumstances require states to pass legislation under threat of sanctions against the state governments or officer. ${ }^{82}$ In Printz v. United States, the Court extended this rule to preclude the federal government from commandeering state administrative officials to enforce federal legislation. ${ }^{83}$ These rulings are at best loosely moored to constitutional text or history, but the Court's rulings seem to establish a bright-line, anti-commandeering rule. ${ }^{84}$

It is important, however, to distinguish commandeering of the state from regulation of the state. In Reno v. Condon, a statute that prohibited states from disclosing certain personal information about residents to third parties without consent was upheld as a valid regulation of the state, rather than being struck down as a form of commandeering. ${ }^{85}$ The Court explained:

Any federal regulation demands compliance. That a State wishing to engage in such activity must take administrative and sometimes legislative action to comply with federal standards regulating that activity is a commonplace that presents no constitutional defect. ${ }^{86}$

80. Garcia v. San Antonio Metro. Transit Auth., 469 U.S. 528, 531 (1985); Nat'1 League of Cities v. Usery, 426 U.S. 833, 852 (1976).

81. Garcia, 469 U.S. at 537, 542-43, 542 n.7.

82. New York v. United States, 505 U.S. 144, 149 (1992).

83. Printz v. United States, 521 U.S. 898, 907-08 (1997).

84. Id.

85. Reno v. Condon, 528 U.S. 141, 143 (2000).

86. Id. at $150-51$. 
Thus, regulation of states is permissible even if compliance is costly and requires them to take affirmative legislative or administrative action, provided that the regulation targets the conduct of the state government rather than requiring the state to regulate private parties.

\section{Using Fiscal Powers as Leverage}

Flood insurance exemplifies federal use of funding as leverage to control land use. Flood insurance presents a tricky set of problems. If it is priced too high, people may simply fail to become insured. If it is priced too low, society is in effect subsidizing individuals to build in high-risk areas. Obviously, the solution is to price it "just right," but finding the right level may not be easy, especially since there is no private market to use as a benchmark. ${ }^{87}$ Insurance that is too inexpensive compared to actual risks may actually encourage construction in flood zones. To counter this risk and other development pressures, the government ties the availability of flood insurance to risk mitigation measures, such as land use planning. ${ }^{88}$ This way of using funding to shape behavior will undoubtedly be attractive to Congress. Other options for Congress include using subsidies or tax benefits to encourage climate adaptation or require states to adopt adaptation programs under threat of losing federal funding.

The Supreme Court has given Congress broad discretion over its uses of fiscal power. The Tax and Spend Clause provides: "The Congress shall have Power To lay and collect Taxes, Duties, Imposts and Excises, to pay the Debts and provide for the common Defence and general Welfare of the United States ... ",89 Congress has often used these powers not simply for revenue purposes or to finance government programs but to shape private behavior or state programs. ${ }^{90}$

87. For a critique of FEMA's pricing, see GENERAL ACCOUNTABILITY OFFICE, FloOd InSURANCE: FEMA's RATE-SETTING PROCESS WARRANTS ATTENTION (GAO-0912 Dec. 2008), http://www.gao.gov/new.items/d0912.pdf.

88. See Oliver A. Houck, Rising Water: The National Flood Insurance Program and Louisiana, 60 TUL. L. REV. 61, 64 (1985); see also Federal Emergency Management Agency, Answers to Questions about the NFIP: Floodplain Management (2006), http://www.fema.gov/business/nfip/fldmanre.shtm ("When a community chooses to join the NFIP [National Flood Insurance Program], it must require permits for all development in the SFHA [Special Flood Hazard Area] and ensure that construction materials and methods used will minimize future flood damage. Permit files must contain documentation to substantiate how buildings were actually constructed. In return, the Federal Government makes flood insurance available for almost every building and its contents within the community.").

89. U.S. CONST., art. I, \& 8, cl. 1.

90. See, e.g., South Dakota v. Dole, 483 U.S. 203 (1987) (Congress using conditions on highway spending to force states to lower drinking age); Rumsfeld v. Forum for Academic \& Institutional Rights, Inc., 547 U.S. 47, 70 (2006) (Congress uses 
The Supreme Court has made the breadth of the spending power clear. A century ago, the Court upheld a discriminatory tax on margarine, clearly intending to disfavor the product. ${ }^{91}$ Closer to the middle of the twentieth century, the Court upheld a special tax on bookies, despite the effect of the tax in deterring the activity. ${ }^{92}$ The leading case on the taxing power is now Steward Machinery v. Davis, which upheld the unemployment compensation provisions of the social security law. ${ }^{93}$ These provisions established a federal taxing and conditional spending program to encourage the states to adopt federal unemployment compensation standards. ${ }^{94}$ The federal statute imposed a federal payroll tax on employers, but the employer received a tax credit for any contributions made to a qualifying state plan. ${ }^{95}$ Among other requirements to qualify for the tax credit, a state plan had to place its contributions in a federal trust fund. The Court found that these provisions gave a legitimate inducement for states to participate in the plan rather than coercing them to do so. ${ }^{96}$

Thus, it would be appear to be proper for the federal government to place a tax on construction in flood zones or on conversion of wetlands to dry land. Similarly, Congress could offer tax credits for landlords who provide air conditioning to low income tenants, or Congress could allow faster depreciation rates for investments located in less vulnerable areas in order to encourage investment in those regions.

The problem of conditions on spending is trickier. South Dakota $v$. Dole is the leading modern case recognizing a mild constitutional constraint on the federal government's use of conditional grants to pressure states into adopting federal requirements. ${ }^{97}$ In Dole, Congress withheld certain highway funding from any state that allowed eighteenyear-olds to purchase alcohol. The Twenty-Third Amendment, which repealed prohibition, seems to give states the right to set their own rules

conditions on spending for higher education to force colleges to give access to military recruiters, despite objections that military's "don't ask don't tell" policy violates campus anti-discrimination rules governing interviews by employers).

91. McCray v. United States, 195 U.S. 27, 64 (1904); see United States v. Doremus, 249 U.S. 86, 95 (1919) (upholding a tax on opium that was combined with a special inspection apparatus).

92. United States v. Kahriger, 210 F.2d 565, 571-72 (3d Cir. 1954).

93. Steward Machinery v. Davis, 301 U.S. 548, 574-75 (1937).

94. Id. at 574-76.

95. Id. at 574.

96. Id. at 598 .

97. South Dakota v. Dole, 483 U.S. at 210-11. 
in such matters. Nevertheless, the Court upheld the statute. The Court rejected the claim that the Constitution forbids the use of the spending power to accomplish objectives that are otherwise outside of Congress's power. The Court found that the drinking age limitation was germane to the purpose of the highway funding because Congress wanted the funds to be used to provide safe highways, and underage drinkers present a higher risk of unsafe driving. ${ }^{98}$ Thus, in using funding as leverage, Congress is restricted in its choice of "currency;" the funding has to be related to the leveraged activity.

The Dole Court also emphasized that only five percent of the state's highway funds were at issue, so the statute provided a mild inducement rather than a coercive threat. ${ }^{99}$ Thus, Congress could offer the states financial benefits in order to get them to comply, but it could not make the stakes too high. In other words, there is a somewhat ill-defined price control regime in the market for constitutional rights - the federal government can offer some inducement but not too strong an inducement.

The germaneness and proportionality requirements - or to put it another way, the currency and price controls - have serious drawbacks. First, because these restrictions block exchanges that the parties actually desire, they are likely to be met by evasion. If states are really willing to do something in return for receiving money in another program, and if Congress wants to offer this bargain, it is as difficult to prevent such deals from being made as it is to prevent any other victimless crime. It is especially difficult to block these restrictions when the parties have a long-term or repeat relationship because denying legal enforceability will not necessarily prevent informal quid pro quos. Second, Dole entails line-drawing problems about the degree of germaneness and the scale of the inducement, as well as inviting drafters to phrase the purpose of the statute in such a way as to connect with spending conditions. Finally, it seems a bit paternalistic toward state governments to "protect" them from getting funding in return for agreeing to conditions. Adults and sovereign governments can normally enter into whatever bargains they choose, with no one demanding to know if the promise of one party is germane to the quid pro quo of the other or whether one party is being offered too large of an inducement. Why should state governments be treated differently, as if they were underage adolescents or mental incompetents in need of protection from ill-advised agreements?

Despite these drawbacks, Dole is clearly the law. It offers ample room for the use of funding conditions to induce states or private parties

98. Id. at 210-12.

99. Id. 
to agree to modify their conduct. Thus, Congress can condition funding for state infrastructure on compliance with adaptation standards for that infrastructure or the users of the infrastructure. It can use flooding insurance or other financial inducements to get cities and states to restrict development in vulnerable areas. Likewise, it can restrict public health funding to only those locales that have adequate programs to deal with heat waves.

\section{CONCLUSION}

As we saw in Part I, climate change will have major impacts on the United States, including flood risks and loss of coastal areas from sea level rise, more severe droughts in some areas, and increases in some public health risks. These potential impacts will require difficult and expensive adaptive measures. In a federalist system, different levels of governments are likely to share responsibility for these responses.

Climate adaptation is likely to elicit a mix of federal and state responses. State and local governments will do much of the heavy lifting. The federal government has a role to play, however, where state governments are ineffective, where there are interstate spillover effects, or where strong equitable considerations come into play. That federal role may take the form of creating adaptation requirements that must be met by state and local governments and the private sector. Alternatively, the federal government may use its taxing or spending powers to provide incentives for adaptation. As we saw in the last section, the applicable constitutional doctrines are complex and may limit some forms of federal intervention such as federal directives that states regulate private activities. But the Constitution will restrain the federal government, if at all, only at the margins.

The future importance of these issues depends in part on what actions society takes to limit emissions and mitigate climate change. On the one hand, climate adaptation may be a relatively low-level priority if we avoid tipping points and rigorously control emissions. On the other hand, if effective mitigation does not take place and society is faced with massive climate impacts, adaptation will become one of society's highest priorities. In either event, all levels of government will be called upon to play a role in dealing with the impacts of climate change

Hopefully, mitigation will be swift and effective, making this Article marginal in importance. But without mitigation, adaptation will loom 
large, and the issues discussed in this Article will shape state and federal responses to climate change for decades, if not centuries, to come. 